\author{
RYSZARD BALICKI \\ ORCID: 0000-0002-9192-908X \\ Uniwersytet Wrocławski \\ Katedra Prawa Konstytucyjnego
}

\title{
KLASYFIKACJA FUNKCJI SEJMU RP
}

\begin{abstract}
Abstrakt: Artykuł został poświęcony zagadnieniu klasyfikacji funkcji realizowanych przez Sejm RP po przystąpieniu Polski do Unii Europejskiej. W związku z dokonaną integracją, a zwłaszcza zmianami, które zaszły po wejściu w życie traktatu z Lizbony, konieczne staje się dokonanie na nowo podziału kompetencji realizowanych przez parlament. Autor przedstawia stosowane sposoby klasyfikacji i uzasadnia konieczność uzupełnienia ich o nową funkcję — funkcję europejską Sejmu RP.
\end{abstract}

Słowa kluczowe: Sejm, parlament, kompetencje, funkcje parlamentu, UE

1. Konstytucja Rzeczypospolitej Polskiej z 1997 roku określa, że suwerenem w Polsce jest Naród ${ }^{1}$, który — zgodnie z regulacją zawartą w art. 4 ust. 2 Konstytucji - sprawuje władzę przez swoich przedstawicieli bądź bezpośrednio. Podstawową formą jest jednak system rządów przedstawicielskich, do którego funkcjonowania konieczne jest istnienie Sejmu RP (oraz Senatu RP). Pozycja ustrojowa parlamentu (zarówno rozpatrywanego jako całość, jak i poszczególnych jego izb) wynika z miejsca zajmowanego w systemie organów państwowych i jest determinowana przez pełnione przez niego funkcje ${ }^{2}$.

Problematyka funkcji realizowanych przez parlament od zawsze była przedmiotem zainteresowania doktryny prawa. Walter Bagehot w The English Constitution — klasycznym już dziele z 1867 roku — wyróżnił następujące funkcje pełnione przez Izbę Gmin:

- wyborczą (elective function),

- wyrażania poglądów (expressive function),

- wychowawczą (teaching function),

— informacyjną (informing function),

${ }^{1}$ Art. 4 Konstytucji RP (Dz.U. z 1997 r. Nr 78, poz. 483 ze zm.).

2 Zob. R. Mojak, Parlament a rząd w ustroju Trzeciej Rzeczypospolitej Polskiej, Lublin 2007, s. 115 . 
- prawodawczą (the function of legislation) ${ }^{3}$.

Wszystkie funkcje wskazane przez W. Bagehota także dzisiaj są realizowane przez parlamenty, jednak ich znaczenie - zwłaszcza w odbiorze społecznym - uległo niekiedy istotnym przemianom. W szczególności funkcja prawodawcza (ustawodawcza), umieszczona przez W. Bagehota jako ostatnia, przyjmowana jest współcześnie za najważniejszą. To właśnie tworzenie prawa jest bowiem pierwszym skojarzeniem, które pojawia się w umysłach obywateli po usłyszeniu słowa „parlament”4. $Z$ tak rozumianym ujęciem parlamentaryzmu trudno polemizować, jednak funkcjonowanie ciała przedstawicielskiego, zwłaszcza w państwach zorganizowanych wokół parlamentarnego systemu rządów, jednoznacznie ukazuje, że głównym projektodawcą prawa jest władza wykonawcza. Rola parlamentu stała się na swój sposób wtórna - parlament z zasady uchwala to, co przedkłada rząd, wybrany przecież przez tenże parlament i cieszący się jego zaufaniem ${ }^{5}$.

2. Niezależnie od zachodzących przez lata zmian tematyka typizacji funkcji parlamentu pozostała ważna i nadal budzi zainteresowanie. W Polsce jest to szczególnie widoczne, albowiem doktryna polskiego prawa konstytucyjnego nie wypracowała spójnego katalogu funkcji Sejmu.

Niektórzy autorzy, mając świadomość trudności jednoznacznego zdefiniowania samego pojęcia „funkcje”, rezygnują z jego stosowania, ograniczając się do używania w zamian wyłącznie pojęcia „kompetencje Sejmu”. Czyni tak między innymi Zbigniew Witkowski, który wyróżnia sześć grup kompetencji Sejmu: (1) ustrojodawcze, (2) ustawodawcze, (3) kreacyjne, (4) kontrolne, (5) decyzyjne — „W niektórych sprawach polityki wewnętrznej i międzynarodowej” — oraz (6) wewnątrzorganizacyjne ${ }^{6}$.

W literaturze przedmiotu podjęta została jednak próba dookreślenia kryteriów umożliwiających sklasyfikowanie funkcji parlamentu. Warto przyjrzeć się szczególnie pracom dwóch autorów. Jarosław Szymanek dokonał podziału funkcji realizowanych przez parlament na dwie podstawowe grupy. Pierwszą z nich miały tworzyć funkcje o charakterze prawnym, związane z konkretnym obszarem decyzji podejmowanych przez parlament. Autor zaliczył do nich tworzenie prawa, działalność kontrolną oraz kreacyjną. Druga grupa obejmowała funkcje o charakterze politycznym. Do tej kategorii J. Szymanek zaliczył reprezentację, artykula-

${ }^{3}$ Zob. W. Bagehot, The English Constitution, London 1873, s. 118-120, http://socserv.mcmaster.ca/econ/ugcm/3113/bagehot/constitution.pdf (dostęp: 10.01.2020).

${ }^{4}$ Zob. K. von Beyme, Die parlamentarische Demokratie Entstehung und Funktionsweise 1789-1999, Wiesbaden 2014, s. 199.

${ }^{5}$ M. Stanat, Die französische Nationalversammlung und die Europäische Union. Zwischen parlamentarischer Tradition und europäischer Integration, Wiesbaden 2006, s. 52.

${ }^{6}$ Taki sposób ujęcia kompetencji Sejmu RP został zastosowany już w pierwszym wydaniu podręcznika Prawa konstytucyjnego pod redakcją prof. Zbigniewa Witkowskiego; zob. idem, Sejm Rzeczypospolitej Polskiej, [w:] Prawo konstytucyjne, red. Z. Witkowski, Toruń 1998, s. 165. 
cję interesów, legitymizację, kształtowanie opinii publicznej oraz rekrutację elit politycznych ${ }^{7}$.

Andrzej Bałaban zaproponował natomiast, aby w pierwszej kolejności dokonać sprecyzowania reguł, których wykorzystanie pozwoli dopiero na jasne stypizowanie określonych funkcji realizowanych przez Sejm. Uznał więc za konieczne, aby w odniesieniu do każdej z funkcji:

- wydobyta została podstawa kompetencyjna zawarta w normach konstytucyjnych;

— istniał wysoki stopień ogólności funkcji, a definiowany zakres przedmiotowy obejmował istotną sferę funkcjonowania państwa;

- występował zbiór zdefiniowanych kompetencji;

— współistniały zarówno kompetencje merytoryczne, jak i proceduralne.

Po uwzględnieniu tych reguł A. Bałaban zaproponował katalog obejmujący następujące funkcje Sejmu: (1) ustrojodawczą, (2) ustawodawczą, (3) budżetową, (4) akceptacji prawa międzynarodowego, (5) powoływania i odwoływania organów państwowych oraz (6) kontrolną z elementami inspiracji ${ }^{8}$.

Nawet tak rozbudowany katalog kompetencji nie miał jednak charakteru kompletnego. Dlatego też A. Bałaban założył możliwość istnienia dodatkowej kategorii „kompetencji autonomicznych”, które nie mogą zostać przyporządkowane do żadnej z wymienionych przez niego funkcji Sejmu, a są ujęte w Konstytucji RP. Do tak zdefiniowanych form aktywności Sejmu autor zaliczył: prawo Sejmu do zarządzenia referendum, prawo do uchwalenia własnego regulaminu, kompetencje dotyczące stanów nadzwyczajnych, prawo skrócenia kadencji Sejmu oraz regulacje dotyczące statusu posła ${ }^{9}$.

3. Rozbieżności poglądów występujące w doktrynie ulegają wzmocnieniu lakonicznością regulacji konstytucyjnej. W Konstytucji RP literalnie zostały bowiem ujęte jedynie dwie funkcje: ustawodawcza i kontrolna ${ }^{10}$.

Funkcję ustawodawczą sprawują Sejm i Senat na zasadzie wyłączności ${ }^{11}$, co oznacza, że: (1) żaden inny organ nie może stanowić aktów prawnych o mocy prawnej równej ustawie (chyba że taki wyjątek jest expressis verbis zdefiniowany w normach konstytucyjnych — art. 234 Konstytucji RP); (2) kompetencje prawo-

${ }^{7}$ Zob. J. Szymanek, Decydowanie parlamentarne, [w:] Decydowanie publiczne. Polska na tle innych państw członkowskich Unii Europejskiej, red. G. Rydlewski, Warszawa 2011, s. 74.

${ }^{8}$ Zob. A. Bałaban, Pozycja ustrojowa i funkcje Sejmu RP, Warszawa 2011, s. 41-42.

${ }^{9}$ Zob. ibidem, s. 125-130.

${ }^{10}$ Dlatego też na przykład Anna Chorążewska przyjmuje istnienie jedynie dwóch funkcji definiowanych tradycyjnie: prawodawczej i kontrolnej, niejako warunkowo dopuszczając istnienie trzeciej — kreacyjnej; „,można jeszcze co najwyżej wyróżnić funkcję kreacyjną, będącą konglomeratem dwóch poprzednich" - eadem, Sejm RP, [w:] Polskie prawo konstytucyjne na tle porównawczym, red. R.M. Małajny, Warszawa 2013, s. 399 n.

${ }^{11}$ Co oczywiście nie ogranicza możliwości wypełniania swoich kompetencji przez pozostałe organy państwowe uczestniczące w procesie stanowienia ustaw. 
dawcze innych organów państwowych muszą mieć charakter podporządkowany ${ }^{12}$. Konstytucja nie wprowadza przy tym legalnej definicji ustawy ani też nie określa jej zakresu przedmiotowego, pozostawiając te kwestie praktyce ustrojowej, doktrynie prawa konstytucyjnego oraz orzecznictwu (zwłaszcza Trybunału Konstytucyjnego).

Warto przy tym dodać, że w ramach funkcji ustawodawczej (lub jako odrębną, samoistną funkcję) ujmuje się niekiedy także funkcję ustrojodawczą. Jest ona definiowana jako możliwość zarówno dokonywania zmian w konstytucji, jak i uchwalenia nowej ustawy zasadniczej ${ }^{13}$.

Kolejna z funkcji ujętych w Konstytucji — kontrolna — jest nie tylko pierwotną funkcją parlamentu ${ }^{14}$, jej występowanie jest również traktowane jako konieczny element systemu demokratycznego państwa ${ }^{15}$. Związek między odpowiedzialnością polityczną egzekutywy a kontrolą parlamentarną jest współcześnie niekwestionowany. W literaturze przedmiotu podkreśla się, że funkcja kontrolna pozostaje ,istotnym wyrazem funkcjonowania współczesnego państwa demokratycznego"16, a „demokracja i kontrola potrzebują się oraz wzajemnie się warunkują. Są dwiema stronami medalu"17. Za źródło władzy parlamentu do kontrolowania egzekutywy jednoznacznie uważa się zasadę suwerenności narodu ${ }^{18}$, kształtującą fundamenty systemu przedstawicielskiego.

Konstytucyjna regulacja zawarta w art. 95 ust. 2 przesądza też o podstawowych elementach determinujących kształt polskiego modelu kontroli parlamentarnej. Norma konstytucyjna powierza sprawowanie tej funkcji wyłącznie Sejmowi ${ }^{19}$, wskazuje przedmiotowy i podmiotowy zakres kontroli (,nad działalnością

12 Zob. L. Garlicki, Polskie prawo konstytucyjne. Zarys wyktadu, Warszawa 2014, s. 221.

13 Z. Jarosz, Parlament jako organ wtadzy ustawodawczej, [w:] Założenia ustrojowe, struktura i funkcjonowanie parlamentu, red. A. Gwiżdż, Warszawa 1997, s. 183 Zob. też J. Szymanek, Sejm i Senat w porządku konstytucyjnym, [w:] Parlamentaryzm w świecie współczesnym. Między ideq a rzeczywistością, red. T. Mołdawa, J. Zaleśny, Warszawa 2011, s. 200.

${ }^{14}$ O przesłankach ukształtowania się funkcji kontrolnej zob. M. Kruk, Funkcja kontrolna sejmu RP, Warszawa 2008, s. 6 n.

${ }^{15} \mathrm{~W}$ literaturze podkreśla się, że występowanie funkcji kontrolnej jest „pierwszą poszlaką dla istnienia demokracji” (J. Marszałek-Kawa, Pozycja ustrojowa i funkcje Sejmu Rzeczypospolitej Polskiej po akcesji do Unii Europejskiej, Warszawa 2012, s. 395) i tworzy „kościec parlamentarnego systemu rządów" (R. Mojak, Funkcja parlamentarnej kontroli działalności rządu, [w:] Parlament. Model konstytucyjny a praktyka ustrojowa, red. Z. Jarosz, Warszawa 2006, s. 121).

${ }^{16}$ H. Pajdała, Instrumenty kontroli parlamentarnej nad władza wykonawcza (Bułgaria, Czechy, Polska, Stowacja i Węry), [w:] Zagadnienia konstytucjonalizmu krajów Europy ŚrodkowoWschodniej, red. T. Mołdawa, Warszawa 2003, s. 62.

${ }^{17}$ S. Höpfner, Parlamentarische Kontrolle in Deutschland und in der Europäischen Union. Das Recht der parlamentarischen Untersuchungsausschüsse des Deutschen Bundestages und des Europäischen Parlaments, Hamburg 2004, s. 57, cyt. za: J. Marszałek-Kawa, op. cit., s. 395.

${ }^{18}$ Hans Kelsen podkreślał, że właśnie instytucje kontroli są gwarancją suwerenności narodu; zob. idem, O istocie $i$ wartościach demokracji, Warszawa 1936, s. 97 n.

${ }^{19}$ Pojęcie „Sejm” w tym wypadku oznacza zarówno izbę działającą in pleno, komisje sejmowe, jak i posłów. W doktrynie toczyła się dyskusja o możliwości wykonywania pewnych kom- 
Rady Ministrów"), a także określa sferę prawnych instrumentów stosowanych w procesie kontroli („w zakresie określonym przepisami Konstytucji i ustaw”) ${ }^{20}$. Uprawnienia kontrolne Sejmu rodzą po stronie zobowiązanych organów władzy wykonawczej skutki prawne poprzez zobowiązanie do określonego zachowania (przedstawienia pożądanych wyjaśnień, osobistego stawienia się itp.).

4. Pozostałe funkcje nie są nazwane w regulacjach konstytucyjnych, są jednak dekodowane przez doktrynę. Najczęściej wymienia się tu funkcję kreacyjną oraz funkcję współkształtowania podstawowych kierunków polityki państwa.

Funkcja kreacyjna Sejmu ${ }^{21}$ polega na uprawnieniu do kształtowania personalnej obsady konstytucyjnych organów państwa. Jednak tylko w niektórych przypadkach funkcja ta może być wykonywana samodzielnie przez Sejm, w pozostałych konieczne jest współdziałanie z innymi organami państwowymi. Wybór piastunów organów może być więc dokonywany w różnych konfiguracjach: samodzielnie przez Sejm, przez Sejm za zgodą Senatu, przez Sejm na wniosek prezydenta lub też odrębnie przez Sejm i inne organy, poprzez wybór części składu osobowego danego organu.

Funkcja współkształtowania podstawowych kierunków polityki państwa jest definiowana przez doktrynę stosunkowo od niedawna ${ }^{22}$. Nie ulega wątpliwości, że w modelu konstytucyjnym przyjętym w Polsce, opartym na zasadzie podziału władzy, odpowiedzialność za prowadzenie polityki państwa powierzona została kolegialnemu organowi władzy wykonawczej - Radzie Ministrów. Zasada podziału władzy nie może być jednak intepretowana jako dążenie do absolutnej separacji władz, z tą zasadą łączy się bowiem zasada wzajemnego oddziaływania władz na siebie, co winno zapewnić systemowi ustrojowemu niezbędną równowagę 23 , oraz - zawarty w preambule do Konstytucji RP — obowiązek współdziałania władz. Możliwość oddziaływania przez Sejm na kształtowanie polityki państwa może być również wydobyta z normy zawartej w art. 146 ust. 2 Konstytucji. Występuje w nim bowiem domniemanie kompetencyjne w zakresie prowadzenia

petencji kontrolnych przez Senat i senatorów; szerzej zob. P. Sarnecki, Kompetencje kontrolne Senatu Rzeczypospolitej Polskiej, „Przegląd Sejmowy” 2000, nr 6 (41), s. 9; oraz J. Szymanek, Rola Senatu RP w wykonywaniu kontroli parlamentarnej (uwagi de lege lata $i$ de lege ferenda), „Ruch Prawniczy, Ekonomiczny i Socjologiczny” 2004, nr 1, s. 15.

20 Szerzej zob. R. Mojak, Funkcja parlamentarnej kontroli..., s. 124-125; zob. też P. Sarnecki, Funkcje i struktura parlamentu wedlug nowej Konstytucji, „Państwo i Prawo” 1997, nr 11-12, s. 47.

${ }^{21}$ Nazwa tej funkcji jest pojęciem zastanym, właściwsze byłoby ujęcie opisowe, precyzujące zakres kształtowanej kompetencji — obsada personalna określonych organów; zob. Z. Jarosz, op. cit., s. 183; oraz W. Sokolewicz, Funkcja kreacyjna Sejmu i Senatu, [w:] Parlament. Model konstytucyjny..., s. 147. Również A. Bałaban, podkreślając nieprecyzyjność terminu „funkcja kreacyjna”, w przedstawionej przez siebie typologii posługuje się terminem ,powoływanie i odwoływanie organów państwowych"; zob. idem, op. cit., s. 80.

${ }^{22}$ Zob. J. Buczkowski, Sejm - Senat - Zgromadzenie Narodowe, [w:] Prawo konstytucyjne RP (instytucje wybrane), red. J. Buczkowski, Ł. Buczkowski, Przemyśl-Rzeszów 2010, s. 250.

${ }^{23}$ Zob. B. Banaszak, Konstytucja Rzeczypospolitej Polskiej. Komentarz, Warszawa 2009, s. $85-86$.

Przegląd Prawa i Administracji CXX, 2020, cz. 1 i 2

(C) for this edition by CNS 
polityki państwa dla Rady Ministrów, jednak z uwzględnieniem kategorii spraw, które mogą być zastrzeżone „dla innych organów państwowych”. Także niektóre normy konstytucyjne wprost określają uprawnienia przysługujące Sejmowi. Szczególne miejsce wśród nich zajmuje prawo Sejmu (i Senatu) do uchwalenia ustawy budżetowej, na której podstawie prowadzona jest gospodarka funduszami publicznymi ${ }^{24}$. Warto przy tym pamiętać, że kompetencja ta może być wywiedziona z historycznego prawa „władzy nad sakiewką", ukształtowanego u początków parlamentu angielskiego ${ }^{25}$.

Do innych kompetencji mieszczących się w ramach omawianej funkcji możemy zaliczyć: uprawnienie Sejmu do ogłaszania stanu wojny i decydowania o zawarciu pokoju (art. 116 Konstytucji RP), wyrażanie zgody na przedłużenie stanu wyjątkowego i stanu klęski żywiołowej (art. 230 ust. 1 oraz 232 Konstytucji RP) oraz uchylenie rozporządzenia Prezydenta RP o wprowadzeniu stanu wojennego lub wyjątkowego (art. 231 Konstytucji RP) czy też wyrażanie zgody na ratyfikację lub wypowiedzenie umów międzynarodowych (art. 89 i 90 Konstytucji RP).

5. Po przystąpieniu Polski do Unii Europejskiej pozycja Sejmu (jak też Senatu) uległa istotnym zmianom ${ }^{26}$. Polski ustawodawca musiał się zmierzyć z nową sytuacją polityczną, w której jego rola została w wyraźny sposób ograniczona — w miejsce dotychczasowej nieograniczonej kompetencji ustawodawczej Sejm musiał zaakceptować fakt, że część jego uprawnień wykonywana będzie przez organy Unii Europejskiej. Równolegle pojawiły się jednak nowe możliwości działania, które zostały zdefiniowane w ustawie kompetencyjnej i polegały na współdziałaniu parlamentu z Radą Ministrów w sprawach związanych z członkostwem w Unii.

Warto w tym miejscu odwołać się do twierdzeń zawartych w uzasadnieniu do wyroku wydanego przez Trybunał Konstytucyjny w sprawie K 24/04. Trybunał podkreślił, że przedmiot rozpatrywanej wówczas sprawy — kompetencje izb ustawodawczych w sprawach europejskich -

ma zasadnicze znaczenie dla kształtowania na przyszłość zakresu partycypacji polskich organów prawodawczych w procesie tworzenia prawa Unii Europejskiej. Przyjmowane w tej dziedzinie rozwiązania prawne muszą konsekwentnie uwzględniać zasadniczą zmianę, która dokonała się z dniem 1 maja 2004 r., tj. w chwili przystąpienia Rzeczypospolitej Polskiej do Unii Europejskiej. W pierwszym rzędzie musi być wzięty pod uwagę fakt, że istotna część tworzonego i obowiązującego od tej chwili prawa będzie determinowana regulacjami wspólnotowymi — także w zakresie ustaw krajowych (ponieważ stanowić będą one w znaczącej mierze implementację uregulowań

${ }^{24}$ Szerzej zob. B. Naleziński, Sejm i Senat, [w:] Prawo konstytucyjne Rzeczypospolitej Polskiej, red. P. Sarnecki, Warszawa 2008, s. 268.

${ }^{25}$ Zob. D.M. Olson, Demokratyczne instytucje legislacyjne. Ujęcie porównawcze, Warszawa 1998, s. 15.

${ }^{26} \mathrm{Na}$ powstanie zmian jakościowych w realizacji funkcji ustawodawczej już w okresie przedakcesyjnym zwrócił uwagę J. Jaskiernia, jednak zdaniem autora nie doszło wówczas do „zasadniczego podważenia konstrukcji funkcji ustawodawczej Sejmu"; zob. idem, Wplyw integracji z Uniq Europejska na funkcję ustawodawcza Sejmu RP, „Studia Prawnicze” 2006, nr 3 (169), s. 19. 
europejskich). Do tej jakościowo zmienionej sytuacji prerogatywy konstytucyjnych organów tworzących władzę ustawodawczą powinny być odpowiednio dostosowane; muszą się one wyrażać w formie zapewniającej tym organom wpływ na treść prawa europejskiego, co najmniej przez współkształtowanie polskiego stanowiska wobec projektów aktów prawnych Unii Europejskiej. Przyjęta argumentacja w pełni uzasadnia tezę, że w rozpatrywanej sprawie chodzi o nową szczególną postać realizacji kompetencji mieszczących się w prerogatywach władzy ustawodawczej27.

Wskazane orzeczenie pozwoliło na sformułowanie tezy o dokonanym zredefiniowaniu pojęcia funkcji ustawodawczej i uzupełnieniu jej o nowe kompetencje, związane $\mathrm{z}$ udziałem $\mathrm{w}$ tworzeniu prawa europejskiego. W takim wypadku doszłoby jednak do zerwania ścisłego związku funkcji ustawodawczej z kompetencją parlamentu do tworzenia prawa powszechnie obowiązującego w Polsce. Tak konstruowana funkcja obejmowałaby także każdą formę oddziaływania Sejmu i Senatu na treść prawa obowiązującego na terenie kraju, w tym „wywieranie choćby nawet pośredniego wpływu na treść aktów prawa unijnego"28.

Co paradoksalne, tak szeroko ujmowana funkcja ustawodawcza ograniczałaby jednak „europejskie” kompetencje Sejmu jedynie do kwestii związanych z partycypacją w tworzeniu prawa europejskiego, a poza stosowanymi sposobami klasyfikacji znalazłyby się pozostałe uprawnienia przysługujące parlamentom narodowym. Należy przy tym podkreślić, że w doktrynie od dawna wyróżnia się co najmniej trzy podstawowe obszary europeizacji funkcji parlamentów, zaliczając do nich: monitorowanie zachowania rządu w pracach organów Unii, ratyfikację zmian traktatowych oraz odpowiedzialność za implementację dyrektyw ${ }^{29}$.

Coraz bardziej zauważalna staje się więc dysfunkcjonalność stosowanych sposobów typizacji, jednak w sposób oczywisty jest to konsekwencja braku korelacji przystąpienia Polski do Unii z potrzebnymi zmianami ustawy zasadniczej. Konieczne i pożądane regulacje statusu izb dokonywane były wyłącznie na podstawie regulacji ustawowych i regulaminowych. W pierwszym okresie integracji nowo otrzymane kompetencje odnosiły się przede wszystkim do elementów kontroli działań Rady Ministrów w zakresie spraw unijnych. Jednak wejście w życie traktatu z Lizbony spowodowało także powstanie nowych form działania Sejmu, których aktywne wykorzystanie może rodzić reakcje na poziomie samej Unii. W efekcie pojawiła się grupa kompetencji, które nie mogły zostać przyporządkowane do żadnej z kategorii występujących w typowych podziałach. Konieczne stało się zatem wyodrębnienie nowej funkcji, obejmującej kompetencje dotyczące europejskiej aktywności izby. Taka koncepcja budziła jednak (i niekiedy nadal bu-

${ }^{27}$ Wyrok TK z dnia 12 stycznia 2005 roku, sygn. K24/04, OTK ZU 2005, nr 1A, poz. 3, http:// ipo.trybunal.gov.pl/ipo/Sprawa?\&pokaz=dokumenty\&sygnatura=K\%2024/04 (dostęp: 20.12.2019).

${ }_{28}$ Zob. M. Granat, Prawo konstytucyjne. Pytania i odpowiedzi, Warszawa 2016, s. 250 n.

${ }^{29}$ Zob. T. Raunio, Holding governments accountable in European affairs: Explaining cross-national variation, [w:] The Europeanisation of Parliamentary Democracy, red. K. Auel, A. Benz, London-New York 2006, s. 17-18. 
dzi) spór w doktrynie polskiego prawa konstytucyjnego ${ }^{30}$. Warto przy tym podkreślić, że teza o niedostosowaniu klasycznego podziału funkcji Sejmu w wypadku państwa przystępującego do Unii Europejskiej została podniesiona już podczas prac nad przygotowaniem ustawy kooperacyjnej z 2004 roku $^{31}$.

6. Po szesnastu latach członkostwa Polski w UE konieczność jasnego zdefiniowania kompetencji parlamentu w sprawach europejskich wydaje się oczywistością i to mimo ograniczeń wynikających z niewystępowania regulacji konstytucyjnej. Doktryna polskiego prawa konstytucyjnego winna to uczynić, mając przy tym świadomość istniejących trudności. Zawsze bowiem będzie problem z jasnym określeniem linii demarkacyjnych między dotychczasowymi funkcjami a projektowaną nową funkcją. Funkcja europejska jest bowiem „odrębna od dwóch pozostałych, a jednocześnie w jakimś stopniu pokrywa się z nimi”32.

Zauważalne jest jednak, że wraz z podejmowanymi w Unii Europejskiej działaniami mającymi na celu wzmocnienie pozycji parlamentów państw członkowskich zwiększa się także akceptacja celowości zdefiniowania zakresu kompetencji przysługujących Sejmowi, a niemogących zostać przyporządkowane do dotychczas stypizowanych funkcji. W szczególny sposób konieczność ta stała się zauważalna po wejściu w życie traktatu z Lizbony ${ }^{33}$. Traktat ten na nowo uregulował bowiem miejsce parlamentów narodowych na scenie europejskiej, a także - co szczególnie ważne - przypisał im wprost określone kompetencje (na przykład bezpośredni udział w procesie stanowienia prawa czy też możliwość wniesienia skargi do Trybunału Sprawiedliwości Unii Europejskiej). Nowo przyznane kompetencje - co warto podkreślić — funkcjonują wyłącznie na podstawie norm prawa pierwotnego UE.

Funkcja europejska wyróżnia się swoim złożonym charakterem, wynikającym zarówno ze specyfiki źródeł (normy nie tylko krajowe, lecz także prawa europejskiego), jak i zakresu samych kompetencji wchodzących w jej skład. Nie można jej też traktować jako rozwinięcie klasycznie rozumianych funkcji parlamentu ${ }^{34}$. Łączy bowiem w sobie zarówno kompetencje dotychczas ujmowane jako część funkcji dotychczasowych, jak i obejmuje kompetencje nowe, powstałe na skutek dokonującej się integracji europejskiej. Jest więc efektem przeobrażeń mających na celu swoistą , parlamentaryzację” Unii Europejskiej. Również zakres kompetencji mieszczących się w ramach funkcji europejskiej Sejmu będzie ule-

${ }^{30}$ Zob. w tym zakresie analizę przeprowadzoną przez A. Pudło, Funkcja europejska parlamentów państw członkowskich Unii Europejskiej, „Przegląd Sejmowy” 2015, nr 1 (126), s. 15-18.

${ }^{31}$ Zob. B. Banaszak, R. Balicki, Opinia w sprawie możliwości określenia przez przyszła komisję ds. europejskich stanowiska wiążącego Radę Ministrów na forum Unii Europejskiej, „Przegląd Sejmowy" 2004, nr 4, s. 156.

32 Zob. J. Szymanek, ,Funkcja europejska” Sejmu i Senatu jako ustrojowy efekt członkostwa, [w:] Polska w Unii Europejskiej. XLVI Zjazd Katedr i Zakładów Prawa Konstytucyjnego, Wierzba, 3-5 czerwca 2004 r., red. M. Kruk, J. Wawrzyniak, Kraków 2005, s. 351.

33 Szerzej zob. R. Balicki, Funkcja europejska Sejmu RP, Wrocław 2019, s. 76 n.

${ }^{34}$ Zob. D. Lis-Staranowicz, J. Galster, O zjawisku europeizacji polskiego prawa konstytucyjnego, „Przegląd Sejmowy” 2010, nr 2 (97), s. 41. 
gać modyfikacjom. Będzie się to dokonywało równolegle do zmian zachodzących w układzie zależności i powiązań pomiędzy państwami członkowskimi Unii Europejskiej a jej organami. W takim wypadku zmieniać się będą także uprawnienia realizowane przez parlamenty narodowe, a co za tym idzie również zakres kompetencji mieszczących się $\mathrm{w}$ ramach projektowanej funkcji europejskiej.

\title{
CLASSIFICATION OF THE FUNCTIONS OF THE SEJM OF THE REPUBLIC OF POLAND
}

\begin{abstract}
Summary
The article is devoted to the issue of classification of functions performed by the Sejm of the Republic of Poland after Poland's accession to the European Union. Due to the integration, and especially the changes that took place after the Lisbon Treaty came into force, it becomes necessary to redistribute the powers exercised by the parliament. The author presents the established classification methods and justifies the need to supplement them with a new function - the European function of the Sejm of the Republic of Poland.
\end{abstract}

Keywords: Sejm, parliament, competences, functions of the parliament, EU

\section{BIBLIOGRAFIA}

Bagehot W., The English Constitution, London 1873.

Balicki R., Funkcja europejska Sejmu RP, Wrocław 2019.

Bałaban A., Pozycja ustrojowa i funkcje Sejmu RP, Warszawa 2011.

Banaszak B., Konstytucja Rzeczypospolitej Polskiej. Komentarz, Warszawa 2009.

Banaszak B., Balicki R., Opinia w sprawie możliwości określenia przez przyszła komisję ds. europejskich stanowiska wiążącego Radę Ministrów na forum Unii Europejskiej, „Przegląd Sejmowy” 2004, $\mathrm{nr} 4$.

Beyme K. von, Die parlamentarische Demokratie Entstehung und Funktionsweise 1789-1999, Wiesbaden 2014.

Buczkowski J., Sejm - Senat - Zgromadzenie Narodowe, [w:] Prawo konstytucyjne RP (instytucje wybrane), red. J. Buczkowski, Ł. Buczkowski, Przemyśl-Rzeszów 2010.

Chorążewska A., Sejm RP, [w:] Polskie prawo konstytucyjne na tle porównawczym, red. R.M. Małajny, Warszawa 2013.

Garlicki L., Polskie prawo konstytucyjne. Zarys wyktadu, Warszawa 2014.

Granat M., Prawo konstytucyjne. Pytania i odpowiedzi, Warszawa 2016.

Höpfner S., Parlamentarische Kontrolle in Deutschland und in der Europäischen Union. Das Recht der parlamentarischen Untersuchungsausschüsse des Deutschen Bundestages und des Europäischen Parlaments, Hamburg 2004.

Jarosz Z., Parlament jako organ władzy ustawodawczej, [w:] Założenia ustrojowe, struktura i funkcjonowanie parlamentu, red. A. Gwiżdż, Warszawa 1997.

Jaskiernia J., Wplyw integracji z Unia Europejska na funkcję ustawodawcza Sejmu RP, „Studia Prawnicze" 2006, nr 3 (169).

Kelsen H., O istocie $i$ wartościach demokracji, Warszawa 1936. 
Kruk M., Funkcja kontrolna sejmu RP, Warszawa 2008.

Kudej M., W sprawie klasyfikacji funkcji Sejmu i Senatu, [w:] Konstytucja, wybory, parlament. Studia ofiarowane Zdzisławowi Jaroszowi, red. L. Garlicki, Warszawa 2000.

Lis-Staranowicz D., Galster J., O zjawisku europeizacji polskiego prawa konstytucyjnego, „Przegląd Sejmowy" 2010, nr 2 (97).

Marszałek-Kawa J., Pozycja ustrojowa i funkcje Sejmu Rzeczypospolitej Polskiej po akcesji do Unii Europejskiej, Warszawa 2012.

Mojak R., Funkcja parlamentarnej kontroli działalności rządu, [w:] Parlament. Model konstytucyjny a praktyka ustrojowa, red. Z. Jarosz, Warszawa 2006.

Mojak R., Parlament a rząd w ustroju Trzeciej Rzeczypospolitej Polskiej, Lublin 2007.

Naleziński B., Sejm i Senat, [w:] Prawo konstytucyjne Rzeczypospolitej Polskiej, red. P. Sarnecki, Warszawa 2008.

Olson D.M., Demokratyczne instytucje legislacyjne. Ujęcie porównawcze, Warszawa 1998.

Pajdała H., Instrumenty kontroli parlamentarnej nad władza wykonawcza (Bułgaria, Czechy, Polska, Stowacja i Węgry), [w:] Zagadnienia konstytucjonalizmu krajów Europy Środkowo-Wschodniej, red. T. Mołdawa, Warszawa 2003.

Pudło A., Funkcja europejska parlamentów państw członkowskich Unii Europejskiej, „Przegląd Sejmowy" 2015, nr 1 (126).

Raunio T., Holding governments accountable in European affairs: Explaining cross-national variation, [w:] The Europeanisation of Parliamentary Democracy, red. K. Auel, A. Benz, London-New York 2006.

Sarnecki P., Funkcje i struktura parlamentu wedtug nowej Konstytucji, „Państwo i Prawo” 1997, nr 11-12.

Sarnecki P., Kompetencje kontrolne Senatu Rzeczypospolitej Polskiej, „Przegląd Sejmowy” 2000, nr 6 (41).

Sokolewicz W., Funkcja kreacyjna Sejmu i Senatu, [w:] Parlament. Model konstytucyjny a praktyka ustrojowa, red. Z. Jarosz, Warszawa 2006.

Stanat M., Die französische Nationalversammlung und die Europäische Union. Zwischen parlamentarischer Tradition und europäischer Integration, Wiesbaden 2006.

Szymanek J., Decydowanie parlamentarne, [w:] Decydowanie publiczne. Polska na tle innych państw członkowskich Unii Europejskiej, red. G. Rydlewski, Warszawa 2011.

Szymanek J., ,,Funkcja europejska” Sejmu i Senatu jako ustrojowy efekt członkostwa, [w:] Polska w Unii Europejskiej. XLVI Zjazd Katedr i Zakładów Prawa Konstytucyjnego, Wierzba, 3-5 czerwca 2004 r., red. M. Kruk, J. Wawrzyniak, Kraków 2005.

Szymanek J., Rola Senatu RP w wykonywaniu kontroli parlamentarnej (uwagi de lege lata $i$ de lege ferenda), „Ruch Prawniczy, Ekonomiczny i Socjologiczny” 2004, nr 1.

Szymanek J., Sejm i Senat w porządku konstytucyjnym, [w:] Parlamentaryzm w świecie wspótczesnym. Między idea a rzeczywistościa, red. T. Mołdawa, J. Zaleśny, Warszawa 2011.

Witkowski Z., Sejm Rzeczypospolitej Polskiej, [w:] Prawo konstytucyjne, red. Z. Witkowski, Toruń 1998. 